\title{
Climate Change and Its Effect on Water Resources: A Case Study in Annapurna Conservation Area Project (Acap)
}

\section{Shree Prasad $D^{*}$ and Shiba B}

Department of Sustainable Development and Empowerment Forum, Kathmandu University, India

${ }^{*}$ Corresponding author: Shree Prasad D, Department of Sustainable Development and Empowerment Forum and M.Phil, Kathmandu University, India, Tel: 01-5250105; E-mail: spdevkota@kusoed.edu.np

Received date: Mar 22, 2016; Accepted date: Apr 04, 2016; Published date: Apr 14, 2016

Copyright: @ 2016 Prasad DS, et al. This is an open-access article distributed under the terms of the Creative Commons Attribution License, which permits unrestricted use, distribution, and reproduction in any medium, provided the original author and source are credited.

\begin{abstract}
This paper is about the impact of climate change on the water resources. Mainly it has focused on the consequences of climate change in the people of Annapurna Conservation Area Project (ACAP) area. Both the qualitative and quantitative approach of study was conducted. The data's through survey questionnaire and interview were collected in different places of ACAP area. The main essence of this study is to explore the overall aspects of water resources and its impact on the people that are using the resources. It has tried to find the problems faced by the people on water resources, sources of water resources, pattern of rainfall and how the people are coping with those consequences. The main source of water is lakes; pipelines and river.60\% of the respondents have said that there is change in water resources which is caused by environmental changes, climate change and drying of water resources. Also it has the reasons on how the water quality and quantity are differed from the past 25 years. The main essence of this study is to explore the overall aspects of water resources and its impact on the people that are using the resources.
\end{abstract}

Finally it has tried to observe how the people are taking climate change and its impact on water resources and the climatic hazards that are increased from the last 25 years. More specifically, the climatic hazards on water resources were observed. If we see the findings of the study it clarifies that the water resources are not sufficient. It shows that $50 \%$ of the people have faced climate warming over last 25 years. $60 \%$ have observed the increase of climatic hazards, among them, $54 \%$ said it is flood. So the study shows that $50 \%$ of the people have observed the impact of climate change in water resources.

Keywords: Climate change; Water resources; Climatic hazards

\section{Introduction}

\section{Background}

Nepal is a landlocked country with the natural beauty. It is rich in its natural beauty. And its geography is in fact a boon. Nepal lies between Palaeoartic and Oriental realms, the collision between the Indian subcontinent and the Eurasian continent, which started in Paleocene time and continuous today, produced the Himalayan and the Tibetan Plateau, a spectacular modern example of the effects of plate tectonics [1].

Climate Change (CC) is a significant and lasting change in the statistical distribution of weather patterns over periods ranging from decades to millions of years [2]. So climate change is caused by different reasons. It may be a change in average weather conditions or in the distribution of weather around the average conditions (i.e., more or fewer extreme weather events) [2]. Climate change is closely related in all the sectors [3]. highlights that, "Climate change is caused by factors that include oceanic processes (such as oceanic circulation), variations in solar radiation received by Earth, plate tectonics and volcanic eruptions, and human-induced alterations of the natural world; these latter effects are currently causing global warming, and "climate change" is often used to describe human-specific impacts".
The effects of climate change on water resources are very defenceless then development may not be sustainable and eco-friendly as well. If the temperature increases then the snow-capped mountains starts to melt and there would be destruction because of flood and other disasters. Watershed Planning, 2008 states that, Even greater changes are expected in the future, including a continued rise in temperatures, shifts in rainfall patterns, and increases in certain types of hazardous weather, such as heavy spring rains and heat waves" [4].

\section{Information about Annapurna conservation project area (ACAP)}

ACAP lies in the western part of Nepal. It has covered a huge area for the protection and conservation of flora and fauna. If we see the biological diversity of the Annapurna region, it is equally resembled by cultural diversity. The ethnic and indigenous people like, Gurung and Magar are the main groups in the south, whereas Thakali, Manange and Loba are leading in the north. ACAP area is rich in linguistic diversity too. The people speak their own dialect, and have unique cultures and traditions which really have its natural beauty in the performance. Besides, there is also Brahmin, Chhetri in smaller number in comparison with other castes and they have their own occupations. Hindu, Buddhist and pre-Buddhist religions along with a combination of all these are prevalent across the region. Sarkar has stated that, "The ACAP is a project aimed at promoting sustainable development in the Annapurna region of Nepal". The operational plan of the then King Mahendra Trust for Nature Conservation(KMTNC) 
established the ACAP in 198.The local people reside in the 5 districts of the 57 Village Development Committees (VDCs) of the Annapurna Conservation Area Project (ACAP). The natural and cultural features of ACAP have made it the most prevalent trekking destination in the country, drawing more than 60 percent of the country's total trekkers.

The Annapurna Conservation Area Project (ACAP) is the largest undertaking of NTNC and also the first Conservation Area launched in 1986 and largest protected area in Nepal. It covers an area of 7,629 sq. $\mathrm{km}$. and is home to over 100,000 residents of different cultural and linguistic groups. ACAP is rich in biodiversity and is a treasure house for 1,226 species of flowering plants, 102 species of mammals, 474 species of birds, 39 species of reptiles and 22 species of amphibians (ACAP 2012).

\section{Objectives}

The main objective of this study is:

To explore the impact of climate change on water resources.

To explore the situation of water availability.

\section{Research questions}

What is the present scenario of water availability?

Are water resources affected by climate change?

\section{Climate change and water resources}

Water is essential for life. Without water, one cannot even imagine life. But, " $97.5 \%$ of all the water on Earth is saltwater, leaving only the remaining $2.5 \%$ as freshwater and approximately $70 \%$ of the freshwater available on the planet is frozen in the icecaps of Antarctica and Greenland" [5]. Also the paper highlights that, this leaves only the remaining $0.7 \%$ of the total water resources worldwide accessible for direct human uses. And this water is found in lakes, rivers, reservoirs and those underground sources that are shallow enough to be tapped at an affordable cost. This also is the only amount that is regularly renewed by rain and snowfall and therefore available on a sustainable basis.

Khan [6] states that, "Climate Change refers to the variation in the Earth's global climate or in regional climate over time". Climate change is defined as weather averaged over a long period of time. In the countries like Nepal which has lots of biodiversity can be directly affected by climate change and have a massive disaster with its consequences. One of the effects of climate change in water resources is glaciers are thinning and retreating throughout much of the region. So there are some of the reasons behind the rainfall pattern, lack of water resources, lakes are drying and decrease in level of water in the rivers and streams.

Agrawal et al. [7] said, "The most critical impacts of climate change in Nepal are related to its water resources and hydropower generation, stemming from glacier retreat, expansion of glacial lakes, and changes in seasonally and intensity of perception".

So climate change has its impacts on water resources in Nepal. Parajuli [8], states that, "Mean monthly discharges show that global warming would shift the peak discharge month from August to July, due to the fact the snow cover on mountain tops would melt earlier".

\section{Methodology}

The main purpose of the study is to explore and find the factors that affect water resources and livelihood of people. For this study report we have conducted survey research to get the information regarding climate change and its impact on water resources. The research was conducted within the Annapurna Conservation Area Project. We conducted the survey research study within different area of Ghandruk, Ghorepani, Tadapani. We did the survey research through purposive sampling. There were 10 respondents in the survey regarding the climate change and its impact on resources.

The methodological process is both qualitative and quantitative. In quantitative, survey questionnaire are made and filled up. But in qualitative case, interview and observations in some places were done. Some of the data's are described and some of them are transcribed and interpreted. The meanings are generated and analyzed in the narrative and descriptive forms. The data's are presented in the table for more clarifications on the base of the survey.

\section{Data Analysis and Interpretation}

The data collected from the survey is an interpreted and analyzed. There are both qualitative and quantitative data. Both the data sources are analyzed and interpreted as follows:

\section{Present scenario of water availability}

The present scenario of water availability in the study area is discussed in the (Figure 1).

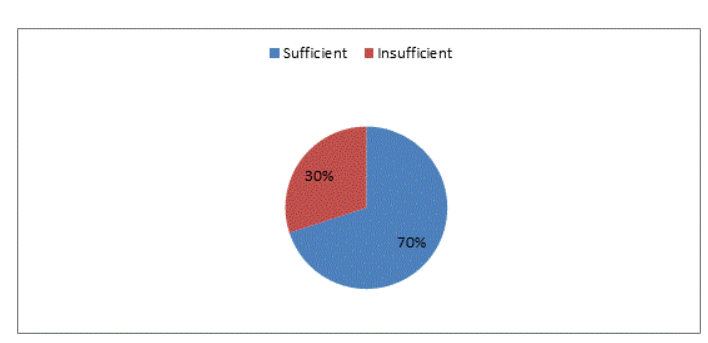

Figure 1: Present scenario of water availability

According to the survey done over Ghandruk, Ghorepani and Tadapani. The chart shows that the water is sufficient. Almost $70 \%$ said that they have sufficient water. Remaining 30\% said that they don't have sufficient water.

\section{Sources of water}

The sources of water that the people of the study area are using are analyzed in the (Figure 2). 


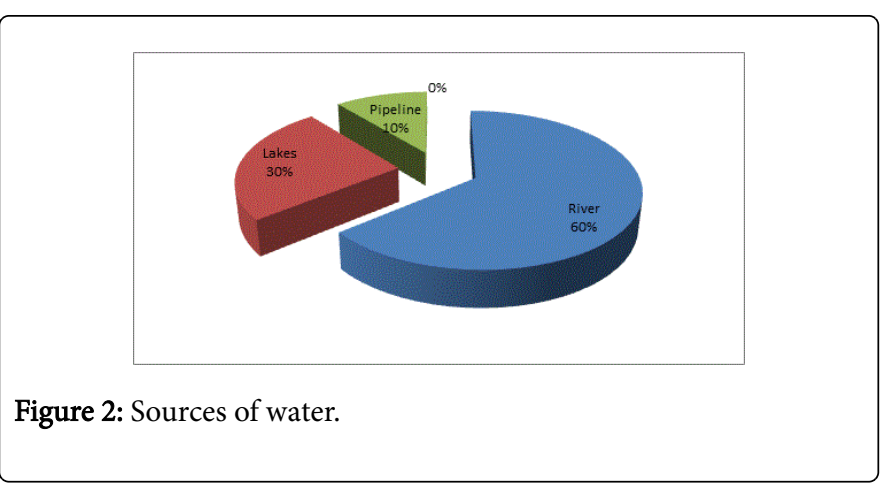

Above chart shows the number of people using River as the source of water is higher. $60 \%$ said that they use water as a source of water. $30 \%$ said that they use lakes. And $10 \%$ said that they are available with pipeline service for water.

\section{Changes seen in water quality}

There are various sources of water that the people of the study area have been using. There are changes in the water quality and the sources too. It has been analyzed in the (Figure 3).

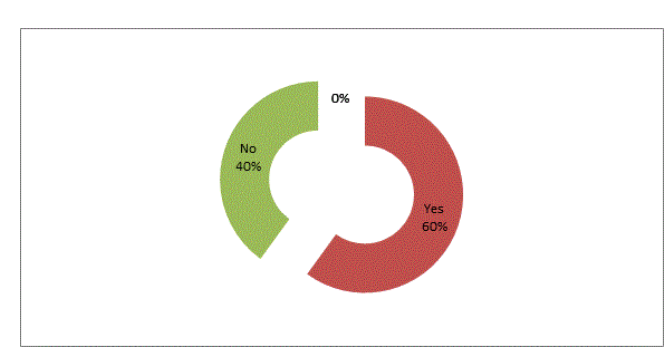

Figure 3: Changes seen in quality of water.

From the above chart it shows that the quality of water is changing. As $60 \%$ people says that the quality in water is decreasing.

\section{Reason behind the changes in water quality and quantity}

Regarding the sources of water there has been changes. Similarly the respondents said that there is change in the quality and quantity of water (Figure 4).

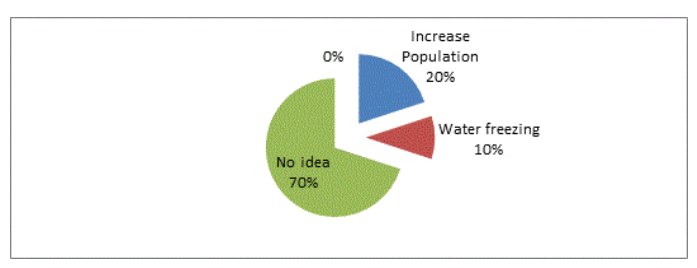

Figure 4: Reason behind the changes in water quality and quantity.

Regarding the changes in water quality $20 \%$ says that population Increase is the reason behind the changes in water quality. Some $10 \%$ says that the water quality during the winter season decreases due to its freezing. Almost $70 \%$ says that they don't have any idea about the changes in water quality and quantity (Figure 5).

\section{Reason behind water scarcity}

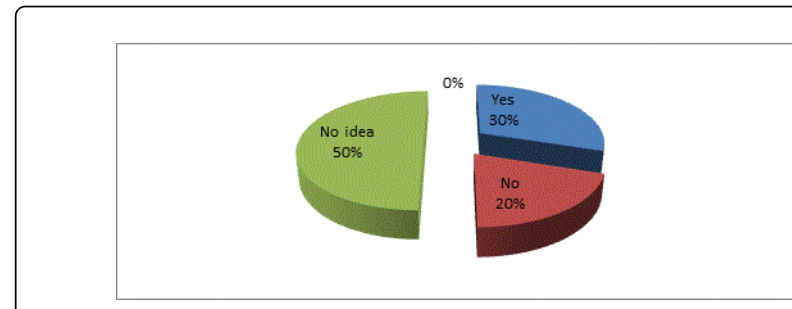

Figure 5: Is climate change the reason behind water scarcity?

The main purpose of this question is to know whether the climate change is the main reason behind. Among the respondents, $30 \%$ said water scarcity is because of climate change.

\section{Change in water resources}

The major changes in water resource are:

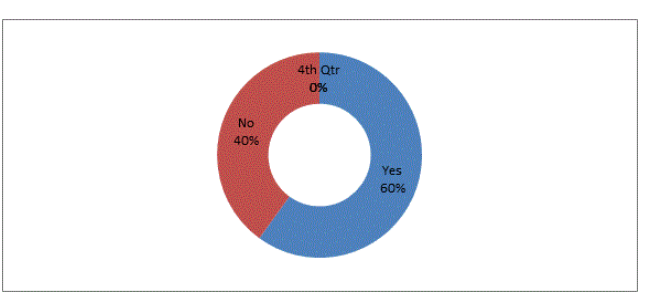

Figure 6: Change in water sources.

The above given (Figure 6) shows that the number of people who changed the sources of water is $60 \%$ and the people using the same sources since $20-25$ years is same.

\section{Reason behind the change in water sources}

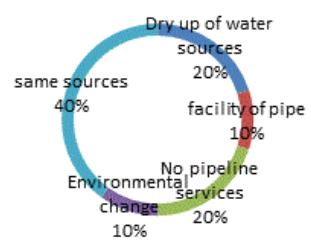

Figure 7: Change in water sources.

The above Figure 7 shows why people changed the sources of water. The figure shows that $20 \%$ of people change their sources because of drying up of water sources. $10 \%$ change their sources because of pipe service facility in their own house. In the beginning $20 \%$ people used to bring the water from the far distance and as soon as the pipeline services available they change their sources. $10 \%$ of people said that they change their water sources due to environmental effects. Whereas remaining $40 \%$ is using the same sources. 


\section{Distance of carrying water}

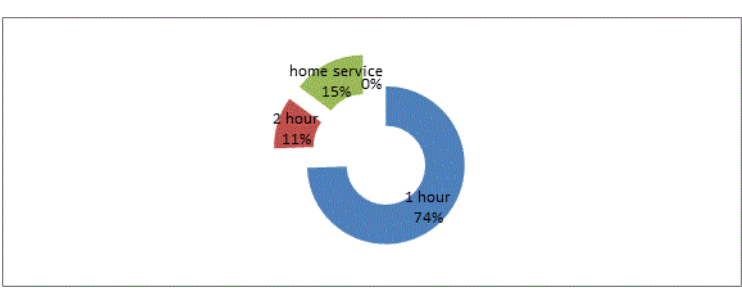

Figure 8: Distance for carrying water.

The above Figure 8 gives the distance of carrying water. 11\% said that they carry the water by taking $2 \mathrm{~h} .15 \%$ said that they have home service. And $74 \%$ said that they walk the distance of $1 \mathrm{~h}$ to fetch the water.

\section{Projects managing water resources}

There are some of the projects that have been helping the local people for water resources.

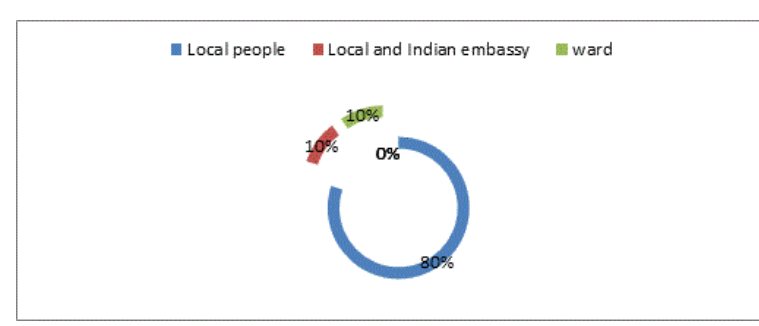

Figure 9: Projects managing water resources.

In the above given Figure 9 it presents that $10 \%$ people said that the water is available with the support of Indian embassy and local people. Another $10 \%$ said that the water is supplied by the ward. Finally the remaining $80 \%$ said that the water is supplied by the effort of the local people themselves.

\section{Water for Irrigation}

This part of the question is about how the people irrigate their field. This is to know whether the water is sufficient for irrigation or not. Also it helps to analyse the sources of water for irrigation (Figure 10).

\section{Use of water in irrigation}

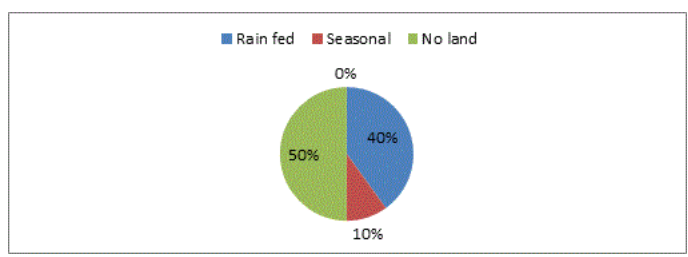

Figure 10: Water for irrigation.
Above given figure says that the irrigation system in the area was done by seasonal by $10 \% .40 \%$ do the irrigation by rain fed and the remaining $50 \%$ said that they don't have any land so that they don't need any irrigation system.

\section{Sufficiency of water for irrigation}

Regarding the sufficiency of water for irrigation what we come to know is $20 \%$ said that the water is not sufficient for their crops. $30 \%$ said that water is sufficient for their crops. As they said that they don't have more land and grow potato and green vegetable for their hotels the water is sufficient. Remaining $50 \%$ said that they don't need the water as they don't have land (Figure 11).

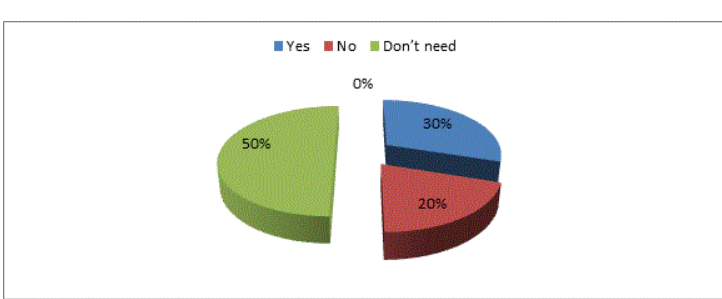

Figure 11: Sufficiency of water for irrigation.

\section{Climate Warming}

This part highlights on how the climate warming is increasing in the last 25 years in the ACAP area (Figure 12).

\section{Over last 25 years}

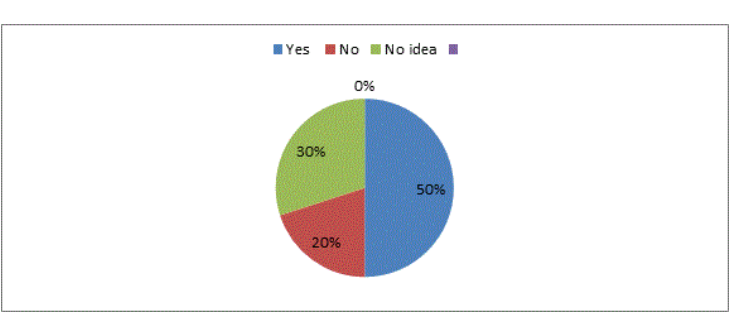

Figure 12: Climate warming over last 25 years.

As we move from the present scenario of water resources to irrigation and now we discourse with the people about whether they feel the climate warming over the last 25 years. $50 \%$ said that they are feeling the climate warming. $20 \%$ said that they didn't feel any climate warming and the remaining $50 \%$ didn't have any idea about the warming.

\section{Increase in dry periods}

Regarding our question about whether there is increase in dry period or not we come to know that almost $50 \%$ said that there is no any increase in dry periods. $40 \%$ said that they are facing the dry periods. And finally remaining 105 said that they don't have any idea about the increase in dry periods (Figure 13). 


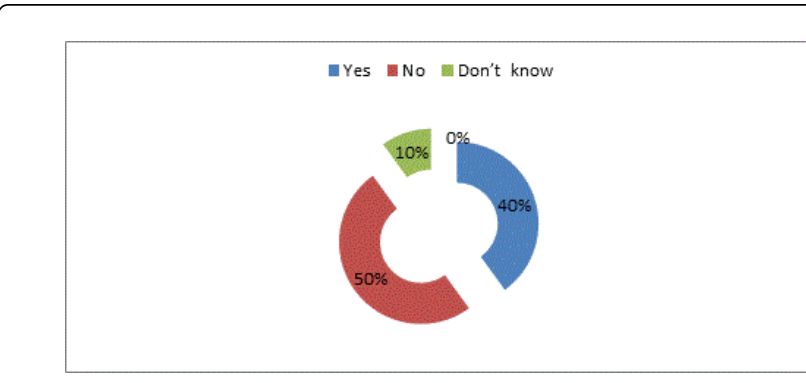

Figure 13: Increase in dry periods.

\section{Increase in climatic hazards}

About our queries regarding the increase in climatic hazards, it is find out that $60 \%$ people said that there is increase in climatic hazards. $10 \%$ said that they are not aware about these things and finally remaining $30 \%$ said that the climatic hazards are not increasing (Figure 14).

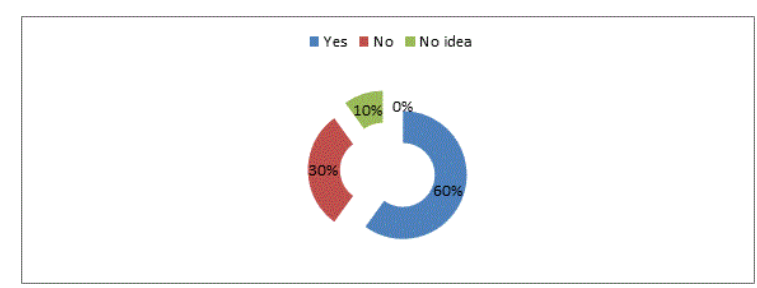

Figure 14: Increase in climatic hazards.

\section{Types of climatic hazards}

Moving towards the different types of climatic hazards above given figure shows that $54 \%$ said that flood is the main climatic hazards that they are facing. $26 \%$ said that they are not facing any climatic hazards. $7 \%$ said that they faced the draught and hailstorm. Another and said that they are facing the problem of hailstorm. 6\% said that they suffered from draught (Figure 15).

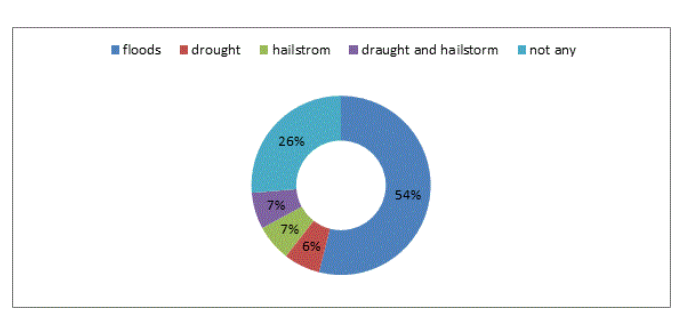

Figure 15: Climatic hazards.

\section{Impacts of climatic hazards on water}

As our main intention was to know the impacts of climate change on water resources, we add our context to the climatic hazards. $30 \%$ said that there is impact of climatic hazards on water resources. $20 \%$ said that they don't have any idea regarding this issue. 50\% said that climatic hazards are not the causes for bringing any changes in water resources (Figure 16).

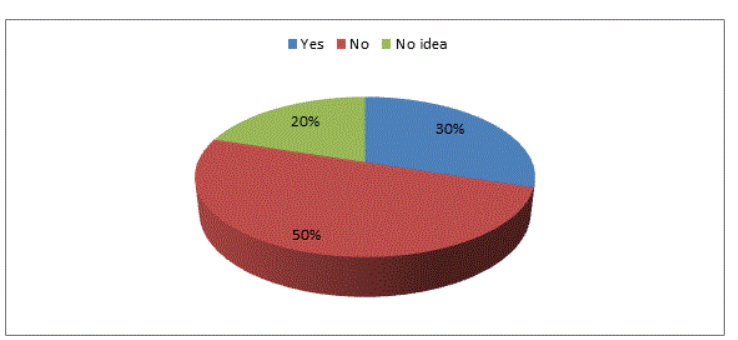

Figure 16: Impacts of climatic hazards on water.

\section{Findings, Conclusion and Recommendation}

Summary of the findings of the study has been discussed and a conclusion has been derived.

\section{Findings}

Climate change has been taken as a global problem. In the same way the respondents also has told that climate change has great impact on water resources and other natural resources. If the timely information is not provided then there may be great consequences. Some of the major findings are given below:

- The majority of respondents (70\%) say there is sufficient water, however (30\%) of them said they lack water.

- Mainly they face scarcity during winter season because water freezes in pipe due to cold.

- River is the main source of water $60 \%$, lakes and pipeline supply $30 \%$ and $10 \%$ are other supply.

- Quality of water is decreasing.

- People have no idea on how the quality of water differs. However some of them said population increase is a reason of degradation of quantity of water.

- Majority of $60 \%$ people have been changing source of water, $40 \%$ have been using the same source since last 20-25 years.

- People change the source of water because of drying water (20\%), pipeline service (10\%), distance of water sources $(20 \%)$, environment effect (10\%), no change (40\%).

- People spend 1-2 h for water (90\%)

- Local initiation (80\%), Support ward (40\%) and support of Indian embassy (10\%) are used for water supply.

- Seasonal irrigation, rain fall irrigation is common ways of irrigation. However $50 \%$ have no land so they need no irrigation.

- As they depend on rain fall and seasonable quantity of water is not sufficient for irrigation.

- Climate is getting warmer over less 25 years, $50 \%$ have no idea of such condition.

- Increased dry period is experienced by $40 \%, 10 \%$ have no idea, $50 \%$ experienced no increase in dry period.

- Study area faces the climate hazard (60\%).

- Flood is the main hazard, drought and hailstorm are other hazards in the area.

- The impact of hazard on water resources is less experienced. 
Citation: Prasad DS, Shiba B (2016) Climate Change and Its Effect on Water Resources: A Case Study in Annapurna Conservation Area Project (Acap). J Climatol Weather Forecasting 4: 159. doi:10.4172/2332-2594.1000159

Page 6 of 6

\section{Conclusion and recommendation}

This small scale survey indicates people in the area have been facing effect of climate change such as decreased sources of water, increased dry season, flood, draught, and hailstorm. There are just the initial sign for great disaster of future.

ACAP is a beautiful area of Nepal with adventure tourism perspectives. However people in the area have fallen into crisis of water crisis. They have to walk $1-2 \mathrm{~h}$ long to manage the water to promote tourism preserving natural beauty. The people of the ACAP area don't have enough knowledge regarding climate change and also its impact and consequences on water resources.

Through the case study and the findings, we can conclude that the residents of the ACAP area don't have enough information regarding climate change and its impact on water resources. And also they haven't face so many problems regarding climate change and its effect on water resources. So some of the recommendations are as follows:

- Easy way of local water supply should be identified.

- Climate change awareness through campaign or other program should be conducted.

- Long term and short term plan to address local problem should be implemented.

- Big scale research study to find real situation of the area is needed.
- Future study to focus the local problem from tourism perspectives is needed.

- Government agencies should pay attention to preserve the local natural resources to promote ACAP tourism.

\section{References}

1. National Trust for Nature Conservation (2012). Climate change impact on livelihood and natural resources of upper Mustang 1-24.

2. Tiwari DP, Nayak HC (2015) Climate change and its impact on global health. International Journal of Recent Research in Interdisciplinary Science 2: 29-38.

3. Kankia NA (2012) Issues in Physics, Environment and Sustainable Development. Journal of Educational and Social Research 2: 140-143.

4. He W (2012) An Evaluation of prairie producer attitudes towards Climate Change. Unpublished Master's Thesis. University of Saskatchewa.

5. Government of Nepal (2011) Water Resources of Nepal in the Context of Climate Change.

6. Khan SA (2010) Global warming and climate change. New Delhi: RVS Books.

7. Agrawal S, Raksakulthai V, Aalst MN, Larsen P, Smith J, et al. (2003) Development and climate change in Nepal: Focus on water resources and hydropower 16-42.

8. Parajuli R (2010) Climate Change and local impacts-synergy between adaptation and renewable energy development for Nepal 1-29. 